\title{
THE EFFECTIVENESS OF BRAND PERSONALITY DIMENSIONS ON BRAND LOYALTY: A STUDY ON MOBILE TELECOMMUNICATION SERVICES IN SRI LANKA
}

\author{
Silva, R.N ${ }^{1}$ and Fernando, P.M.P ${ }^{2}$ \\ ${ }^{1,2}$ University of Kelaniya, Sri Lanka
}

\begin{abstract}
Telecommunication sector has evolved as a major business trend in worldwide. It is one of the major commercial activities in Sri Lanka also where many competitors are playing with different strategies to win a larger market share. This research is focusing on the mobile telecommunication industry in Sri Lanka where the industry players are using carefully planned marketing strategies to attract more customers into their share. The research is taking the approach of investigating the effectiveness of Brand Personality Dimensions on creating Brand Loyalty within the industry. Building upon the prior research on the concepts, Aaker's Brand Personality Scale was used as the base to measure the brand personality and attitudinal and behavioral loyalties were used to measure brand loyalty within the mobile telecommunication sector. The primary data was gathered using a self-administrated questionnaire from 100 users of mobile telecommunication networks using convenience sampling technique within the Western Province of Sri Lanka. The results indicated that the most important brand personality dimensions associated with the brand loyalty in the Sri Lankan mobile telecommunication industry were Excitement and Sincerity. Further it was found that Sophistication, Competence and Ruggedness dimensions of brand personality also significantly affects brand loyalty. Implication of the findings were highlighted and discussed based on the research findings.
\end{abstract}

Keywords: Brand personality, brand loyalty, mobile telecommunication industry.

\section{INTRODUCTION}

\section{Background of the Study}

Mobile telecommunication is one of the main businesses in services sector in the Sri Lankan market. With a total population of 20.5 million in 2013 (Central Bank Report, 2014), there is a remarkable identification of 20.3 million users of mobiles by the end of December 2013 (Telecommunications Regulatory Commission Statistics, December 2013). With such a situation spread out among the customers, it can be realized that the mobile had become like a life partner for customers. Providing telecommunication services and support to the mobile phone users is another sector which is rapidly spreading in every corner of Sri Lanka.

\section{Industry Overview}

Mobile connections grew by $8.9 \%$ during the year 2014 compared to a $5.7 \%$ rise in fixed line connections (News.lk). By end 2014, the fixed telephone penetration (connections per 100 persons) and the mobile telephone penetration stood at 13.0 and 107.0, respectively (News.lk). According to the year 2013 market share Dialog leads the mobile telecommunication industry in Sri Lanka, Mobitel stands as seconds to the Dialog while they are showing a rapid increment during the last few years (Figure 1.). Etisalat, Airtel \& Hutch are staying next to the Mobitel. 


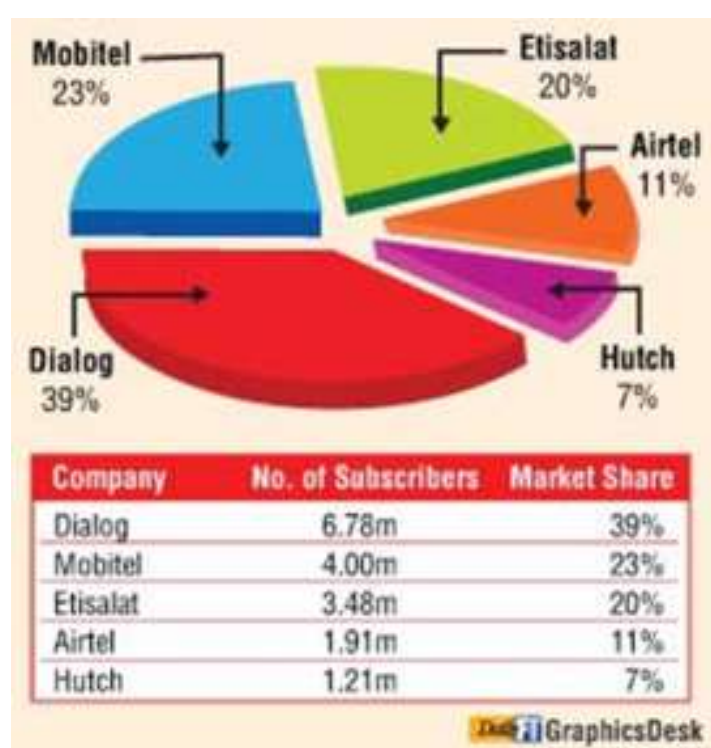

Figure 1: Mobile Telecommunication Connections Market Share

Source: Daily FT, December 2013

The usage of mobile communication services are rapidly increasing among customers and the increased competition between mobile operators through promotional schemes, value added services with local and international services, and competitive pricing, coupled with the ease of obtaining services, internal labour mobility and increased incomes had been highlighted as some of the reasons of the changes in the sector (Daily FT, July 2013).

\section{RESEARCH PROBLEM}

Although many researches have conducted research on impact of brand personality of mobile brands towards customer buying intention, no research has been conducted to evaluate the effectiveness of brand personality preferences of customers towards the customer loyalty of mobile telecommunication in Sri Lanka. So there is a considerable research gap for the subjected topic. In Sri Lanka new competitors like Airtel / Hutch are offering many functional benefits and more economical charges to customers to catch the market, but still they are struggling to acquire a larger market share from the industry leaders. It is interesting to investigate whether customers are emotionally attach to some specific mobile telecommunication service provider more than the new comers in to the market. The current research is conducted to investigate up to what extend brand personality preferences of customers' impact on their loyalty among the mobile telecommunication service providers in Sri Lanka.

\section{LITERATURE REVIEW}

\section{Brand Personality}

Brand personality has been defined as the human characteristics or traits that can be attributed to a brand' (Azoulay \& Kapferer, 2003, pp. 151). Brand personalities proposed significant managerial implications with respect to the relationship of consumer with brands. For example, Melin (1997 in Malik and Naeem 2013) states that the reason for building a brand personality is based on the idea that consumers choose which brands to buy in a similar way that they choose which fellow humans to socialize with. Hankinson \& Cowking (1993) points out that the stronger the brand's identity fit together with the customer's, the customer will identify him or herself stronger with the brand and thereby have a stronger relationship. Kim et al. (2001) explained when similarities occur between brand personality and the consumer's self-expression, the consumer might see the brand as a human, or even a companion.

Therefore the brand personality concept provides new horizons for the brand management in rational marketing field (Ambroi, 2005 in Malik and Naeem 2013). Some important variables considered as value of brand personality is the literature includes frameworks in to brand personality, brand quality, attitudes towards brands, intention of future behaviors, attachment to the brand \& trust in the brand.

With Aaker's brand personality dimensions in 1997, a new stream of research has been born which looked into measuring the brand personalities of various brands and their effectiveness. According to Aaker (1997), brand personality is consisting of multi dimension concepts such as Sincerity, Excitement, Competence, and Sophistication \& Ruggedness.

The five dimensions in the model have been developed with subgroups consisting of aspects of the dimension to clarify the character and structure of the dimensions, as seen in figure 2 (Aaker, 1997). She continues by saying that the different dimensions 
influence the consumer in different ways, for example the sincerity, excitement and competence dimensions affects the human's inner personality, while the sophistication and ruggedness dimensions attract consumers who desire this, but do not have it.

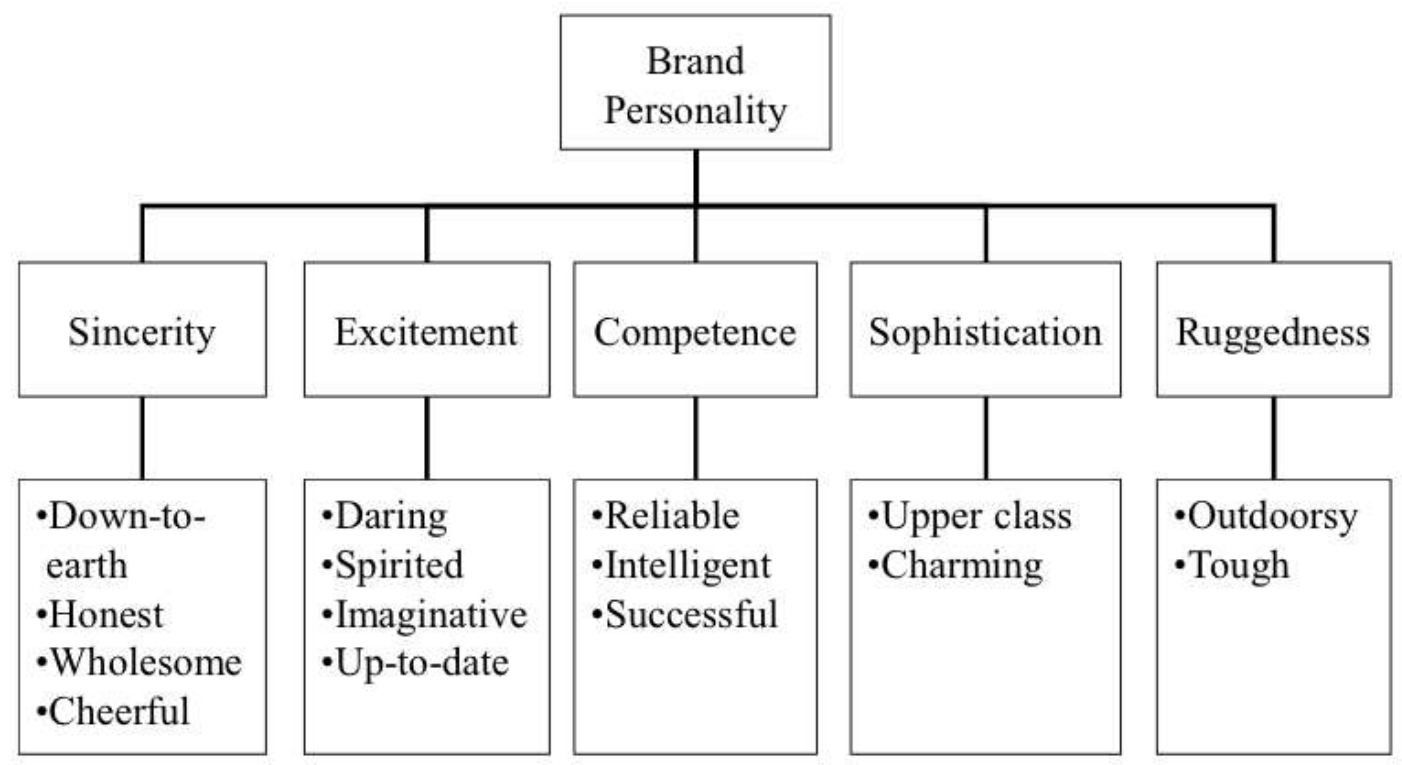

Figure 2: Dimensions of Brand Personality Source: Aaker, 1997

According to Sweeney and Brandon (2006) the brand personality research is very young compared to human personality studies. According to Malik and Naeem (2013) ongoing heavy criticism was leveled against Aaker's multi-dimensional model to measure brand personality construct. Aaker (1997) herself had states that though some factors may work with brands, as well as humans, others may not work in a given category. Finally, the brand personality framework developed by Aaker only includes positive brand attributes, while some brands are not so wholesome (Sweeney \& Brandon, 2006).

\section{Brand Loyalty}

Loyalty is a core dimension of Brand Loyalty. Aaker (1991, p.39) defines brand loyalty as the attachment that a customer has to a brand. According to the Oliver (1999) brand loyalty can be measured through behavioral loyalty and attitudinal loyalty. Behavioral loyalty means the actual behavioral responses getting the precise data from the company's cooperation; however it cannot identify the spurious and latent customers (Dick and Basu, 1994). Attitudinal loyalty with attitude and behavior intent provides value to the company leading to the true behavior loyalty (repeat purchase) through the customers' survey (Aaker,
1991). Customer loyalty represents the repeat purchase, and referring the company to other customers (Heskett et al. 1994). He also stated that customer loyalty is a figure that may be measured directly as measuring the actual repeated sales to customers.

\section{CONCEPTUAL FRAMEWORK \& HYPOTHESES}

According to the theoretical findings on Brand Personality, the following framework is constructed to investigate the relationship between the independent and dependent variables. 


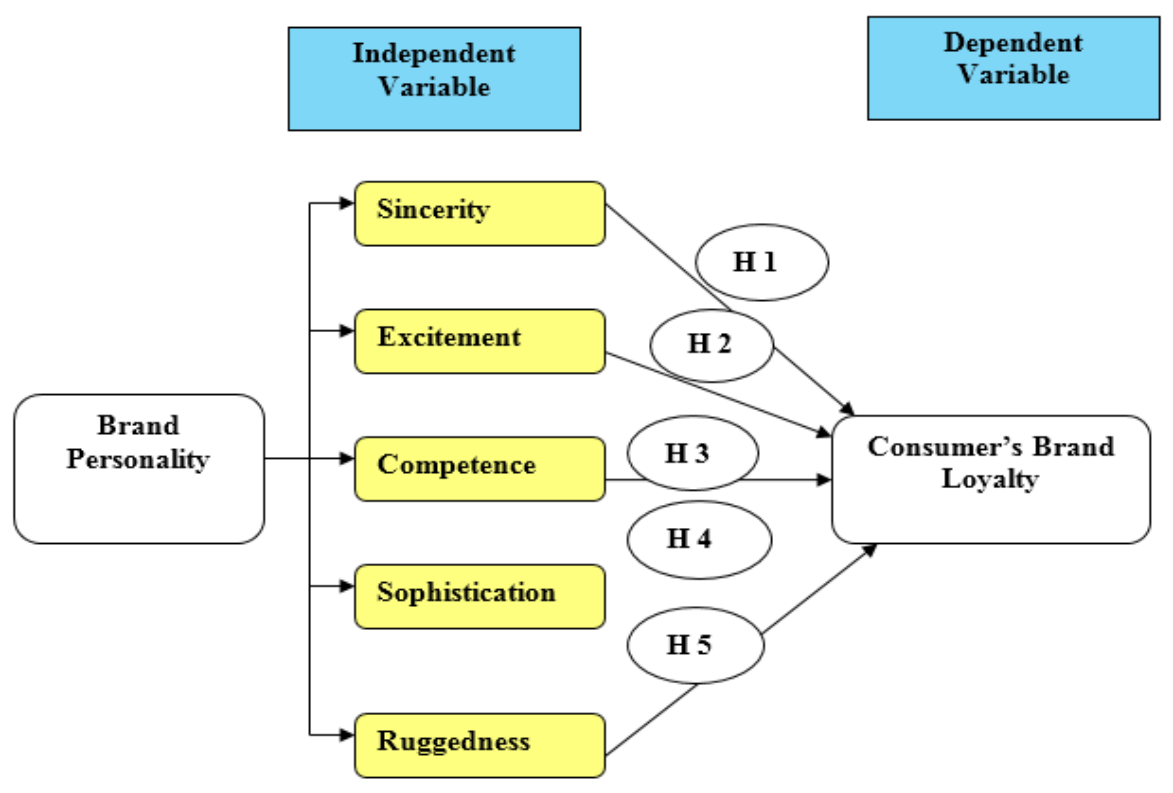

Figure 3: Conceptual Model. Source: Adapted from Aaker, 1997

\section{Hypotheses}

In the hypotheses development, researcher has identified five hypotheses based on the selected variables.

\section{Hypothesis One (H1)}

There is a significant positive relationship between Brand Sincerity \& Consumers' Brand Loyalty on Mobile Telecommunication services in Sri Lanka.

\section{Hypothesis Two (H2)}

There is a positive relationship between Brand Excitement \& Consumers' Brand Loyalty on Mobile Telecommunication services in Sri Lanka.

\section{Hypothesis Three (H3)}

There is a positive relationship between Brand Competence \& Consumers' Brand Loyalty on Mobile Telecommunication services in Sri Lanka.

\section{Hypothesis Four (H4)}

There is a positive relationship between Brand Sophistication \& Consumers' Brand Loyalty on Mobile Telecommunication services in Sri Lanka.

\section{Hypothesis Five (H5)}

There is a positive relationship between Brand Ruggedness \& Consumers' Brand Loyalty on Mobile Telecommunication services in Sri Lanka.

\section{METHODOLOGY}

The research was carried out using deductive approach and focus is on quantitative technique. Both primary data and second data gathering was carried out to identify the impact of brand personality on customer loyalty within the telecommunication sector. A self-administrated questionnaire was developed using Aaker's brand personality framework (1997) to measure customer preferences on mobile telecommunication connections which was reinforced by the literature review of brand personality \& brand loyalty. The questionnaire used 21 likert scale questions and the demographic data and customers' behavioral data were gathered using multiple choice questions, ranking questions, dichotomous questions and open-ended questions. Target population for the survey was customers who are using mobile telecommunication services in Sri Lanka from which a sample of 100 customers were selected using convenience sampling technique from Western Province of Sri Lanka. 


\section{DISCUSSION OF FINDINGS FROM THE RESEARCH}

\section{Reliability Analysis}

Reliability results indicated that the data that was gathered from the questionnaire were reliable. According to the table 1 the Cronbach's Alpha values of all the measured variables are greater than 0.7 which is consistent with Sekaran's (2009) suggestion, alpha over 0.7 are reliable and acceptable.

Table 1: Reliability Analysis

\begin{tabular}{lll}
\hline Scale & $\begin{array}{l}\text { No. of } \\
\text { items }\end{array}$ & $\begin{array}{l}\text { Cronbach's } \\
\text { Alpha }\end{array}$ \\
\hline Sincerity & 04 & 0.741 \\
Excitement & 04 & 0.774 \\
Competence & 03 & 0.758 \\
Sophistication & 02 & 0.722 \\
Ruggedness & 02 & 0.731 \\
Brand Loyalty & 06 & 0.816 \\
\hline
\end{tabular}

\section{Behavioral Data of the Customers}

Under behavioral analysis mainly customers' current mobile connection brand and the retention time period of that connection were analyzed.

\section{Respondents Current Mobile Connection Brand}

As per the figure 4 , the findings revealed that from the sample almost $41 \%$ are using Dialog mobile connections and $25 \%$ are using Mobitel mobile connection. The specialty of the finding is the sample respondents' mobile connection depict the same trend in the industry mobile connection usage where Dialog and Mobitel are leading the market share.

Source: Survey data, 2014

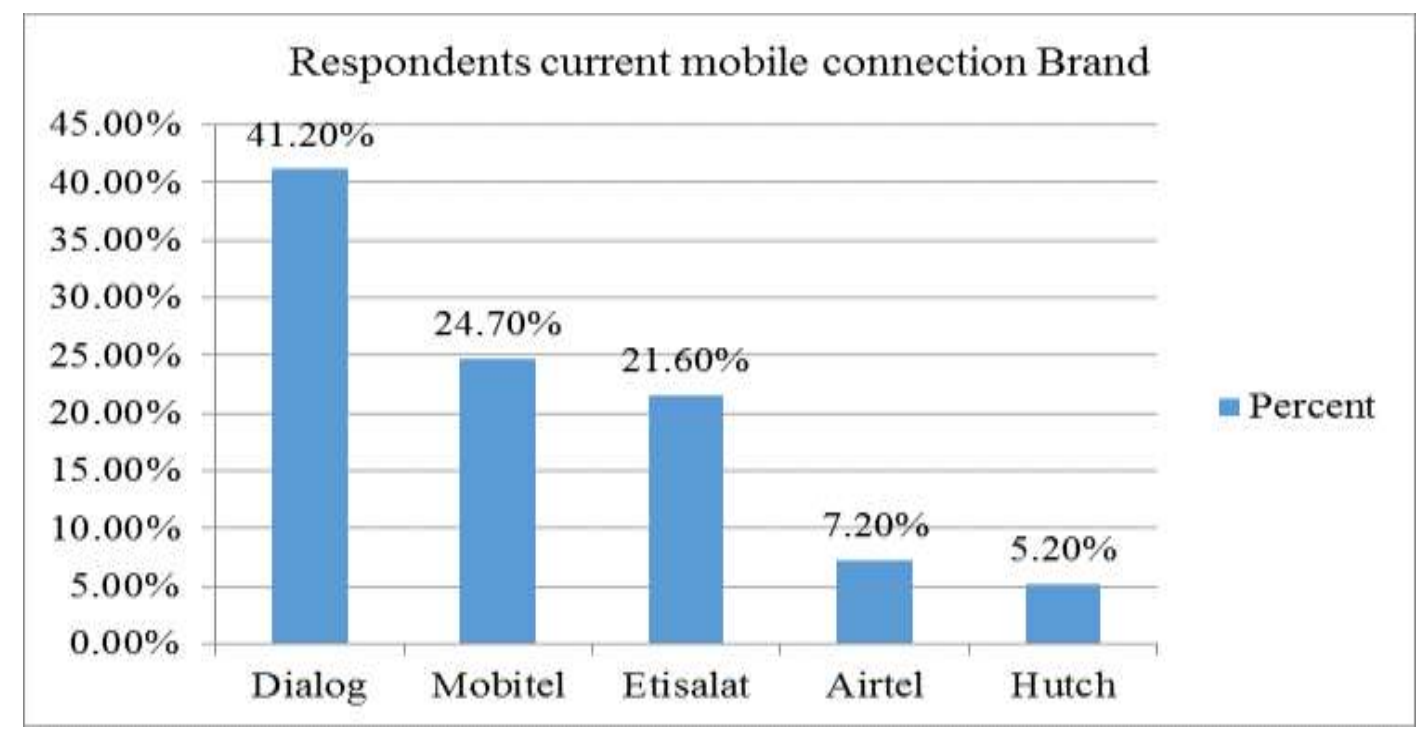

Figure 4: Respondents Current Mobile Connection Brand: Source: Survey data, 2014 


\section{Respondents Retention Period on His/ Her Current Personal Mobile Connection}

The findings also revealed that almost $37 \%$ of the sample had been using the same connection for over five years and almost $20 \%$ had been using the existing connection in between 3-5 years (figure 5). The findings also reveals that most of the customers which is a figure of over $75 \%$ of the sample are having over 01 year of retaining period for their mobile connections which shows that the customers are not only using the connection due to economic benefits.



Figure 5: Respondents Retention Period on His/ Her Current Personal Mobile Connection. Source: Survey data, 2014

\section{Descriptive Statistics}

The mean values of each variables were more than 3 (table 2) which represents all the statements were accepted or respondents were agreed with the statements.

Table 2: Mean Values of Independent \& Dependent Variables

\begin{tabular}{lll}
\hline Description & Variable Name & Mean Value \\
\hline Dependent Variable & Brand Loyalty & 3.6615 \\
Independent Variable & Competence & 3.5842 \\
& Excitement & 3.4845 \\
& Ruggedness & 3.3608 \\
& Sincerity & 3.7139 \\
& Sophistication & 3.4588 \\
\hline
\end{tabular}

\section{Correlation Analysis}

A correlation analysis was carried out for the five independent variables representing customer preferences on mobile connection brand personality identified through Aaker's framework (1997) and the loyalty of customers towards mobile

telecommunication industry. The bivariate correlation procedure was subject to one tailed of statistical significance at a highly significant $(\mathrm{p}<0.01)$ level. 
Table 3: Correlation Analysis Results

\begin{tabular}{llll}
\hline Independent & $\begin{array}{l}\text { Dependent } \\
\text { Variables }\end{array}$ & $\begin{array}{l}\text { Correlation } \\
\text { Value }\end{array}$ & $\begin{array}{l}\text { Significant } \\
\text { Level }\end{array}$ \\
\hline Sincerity & Customer & $.627^{* *}$ & .000 \\
Excitement & Loyalty & $.661^{* *}$ & .000 \\
Competence & & $499^{* *}$ & .000 \\
Sophistication & & $.592^{* *}$ & .000 \\
Ruggedness & & $.485^{* *}$ & .000 \\
\hline
\end{tabular}

**. Correlation is significant at the 0.01 level (1-tailed). Source: Survey data, 2014

Based on Table 3, all five brand personality dimensions were positively correlated to customer loyalty towards mobile telecommunication industry with significant values that were less than 0.01 . Excitement has the highest correlation coefficient (0.661), followed by sincerity (0.627). Sophistication (.592), Competence (.499) and Ruggedness (.485) also showcased a moderate positive correlation with brand loyalty.

\section{Hypotheses Testing}

The correlation coefficients of all five brand personality dimensions demonstrates that there is a moderate positive relationship between each of the dimensions, i.e. Sincerity (.627), Excitement (.661), Competence (.499), Sophistication (.592) and Ruggedness (.485) and customer loyalty among mobile telecommunication users of the country at a 99\% confidence level. Due to this all five hypotheses were accepted.

\section{CONCLUSION AND RECOMMENDATIONS}

All five hypothesis given in the research have been successfully analyzed with the correlations \& it is crystal clear that independent variables of customer preferred Brand personality dimensions such as Sincerity, Excitement, Competence, and Sophistication \& Ruggedness have positive relationship with customer's brand loyalty.

Research could successfully found the brand personality dimension that mostly impact on customer's brand loyalty of mobile telecommunication in Sri Lanka is Excitement (0.661 correlation value). It means that whenever a new comer or existing mobile telecommunication provider comes with a new project, or innovation or even when promoting the existing services, they should highly concentrate on building the appeal through Excitement personality trait. Organizations should take initiatives and should concentrate on daring, spirited, imaginative \& up to date characteristics of the connection or usability in customer mind through their marketing \& promotional campaign.

This research also revealed that secondly most impact customer preferred brand personality dimension is Sincerity ( 0.627 correlation value). The market player's marketing \& operation team should have a wider thinking about how to strengthen the Sincerity through their marketing \& operational activities with down to earth, honest, wholesome \& cheerful characteristics. New comers \& existing giants in mobile telecommunication industry in Sri Lanka should have an ability to maintain the brand personality dimensions of Excitement \& Sincerity both via their business activities. Telecommunication organization should smartly handle their business strategies to balance up these highly impact brand personality dimensions in their brand positioning and communication.

Further when mobile telecommunication organizations are deciding their marketing plan to motivate the customer retention \& customer loyalty, it is not enough to strength the functional activities, but they should consider the emotional stimulation also in customer mind where the above investigations showed that most impact brand personality preferences are Excitement \& Sincerity in Sri Lanka market. 


\section{REFERENCES}

Aaker, D.A. (1991). Managing Brand Equity: Capitalizing on the Value of the Brand Name. New York: The Free Press.

Aaker, J. L. (1997, August). Dimensions of brand personality. Journal of Marketing Research, 34, 347-356.

Azoulay, A., \& Kapferer, J. N. (2003, November). Do brand personality scales really measure brand personality? Brand Management, 11, 143-155.

Central Bank of Sri Lanka Annual Report, 2014.

Dick, A. S. \& Basu, K. (1994). Customer Loyalty: Toward an Integrated Conceptual Framework. Journal of the Academy of Marketing Science, 22, 99-113.

Hankinson, G. \& Cowking, P., (1993). Branding in Action, McGraw-Hill: Berkshire.

Heskett, J., Jones, T., Loveman, G.W and Schlesinger L.A., (March-April, 1994). Putting the service profit chain to work, Harvard Business review. 164

Kim, C. K., D. Han, et al. (2001). "The effect of brand personality and brand identification on brand loyalty: Applying the theory of social identification."

Japanese Psychological Research 43 (4): 195-206.
Malik, M.E. \& Naeem, B. (2013). Aaker's Brand Personality Framework: A Critical Commentary, World Applied Sciences Journal 24 (7): 895-899, 2013.

"Mobile growth boost Sri Lanka's telecoms market" (2013), Daily FT, 30 July 2013, < http://www.ft.lk/2013/07/30/mobile-growth-boost-srilankas-telecoms-market/>.

"Sri Lanka's mobile internet usage grows 85.8-pct in 2014: CB", The Official Government News Portal of Sri Lanka, May 9th, 2015, <http://www.news.lk/news/business/item/7557-sri-lanka-smobile-internet-usage-grows-85-8-pct-in-2014-cb>.

Sekaran, U. (2009). Research Methods for Business: A Skill Building Approach, John Wiley \& Sons.

Sweeney, J.C. \& Brandon, C., (2006). Brand Personality: Exploring the Potential to Move from Factor Analytical to Circumplex Models, Psychology \& Marketing, Vol. 23, Issue 8, p. 639-663.

Telecommunications Regulatory Commission of Sri Lanka - Statistics, December 2013

Oliver R.L. (1999). “Whence Customer Loyalty?” Journal of Marketing, Vol. 63, Special Issue, pp. 33-44.

Plummer, J.T., (2000). How Personality Makes a Different, Journal of Advertising Research, Vol. 40, Issue 6, p. 79-83. 